\title{
International Status and Obligations of Science*
}

\author{
By Prof. A, V. Hirl, F.r.s.
}

$\mathrm{I}^{\mathrm{N}}$ 1796, Britain being then at war with France, 1 a French scientific sailor, Chevalier de Rossel, a prisoner of war in England evidently on parole, dined with the Royal Society Club in London on the invitation of Alexander Dalrymple, the Hydrographer to the Admiralty. The Navy, as well as the Royal Society, clearly regarded scientific standing as entitling its holder to civilised and friendly treatment, regardless of the misfortune of a state of war between the two countries.

Among the instructions issued by the Admiralty to the captain of H.M.S. Rattlesnake, in which Huxley sailed in 1846 as "a surgeon who knew something about science", was the following:

"You are to refrain from any act of aggression towards a vessel or settlement of any nation with which we may be at war, as expeditions employed on behalf of discovery and science have always been considered by all civilized communities as acting under a general safeguard."

Science and learning have for several centuries been regarded by all civilised communities as entitling those who follow them to a certain immunity from interference or persecution-provided that they keep to the rules. This view of the position of science in the world at large does not involve any lack of pride in, or affection for, one's own country; there is in fact as much to say for it from the point of view of old-fashioned chivalry as from that of modern internationalism. Science is a common interest of mankind: whatever the barriers or the difficulties or the struggles between them, civilised societies have accorded a certain immunity and tolerance to people concerned with scientific discovery and learning.

Why should science be singled out in this way? Merely by an ancient privilege based on an aristocratic and capitalistic tradition? Certain Russian colleagues, attending the International Congress on the History of Science in London in 1931, made a vehement and mass protest against the claim that the progress of scientific ideas as such deserves a better place in general historical study. According to them, science must be regarded not for its own sake but simply as the handmaiden of social and economic policy: probably they would protest even more vehemently against my present claim that, in a certain sense, science and learning are superior to and above the State.

Although, historically, privilege may have had something to do with the tolerance shown to science, there is a much better reason for the safeguards given it by decent nations. The reason is that its methods of thought, its direct appeal by experiment to a universal Nature, the new

* From the Huxley Memorial Lecture delivered at Birmingham on November 16. powers given to mankind in general by its application, so obviously do not depend upon the opinions, or emotions, or interests of any limited group, that any civilised people will admit that it transcends the ordinary bounds of nationality. Religion, literature, art depend in part upon customs, emotions, race, climate, age and sex ; the religious instinct, the artistic sense, may be universal enough, but their expressions can be so different that they may lead sometimes to strife rather than co-operation. In science, however, although mistakes are common, one fact remains certain: its discoveries do gradually build up a structure which is approved by all sane men; in the last three hundred years the experimental method, which is universal, has produced results beyond all previous human achievements. It is this universality of its method and results which gives science a unique place among the interests of mankind.

If scientific people are to be accorded the privilege of immunity and tolerance by civilised societies, however, they must observe the rules. These rules could not be better summarised than they were 270 years ago by Robert Hooke. Among Hooke's papers in the British Museum, Weld records a statement, dated 1663, which was probably drawn up after the passing of the Second Charter of the Royal Society. It begins as follows:

"The business and design of the Royal Society is-To improve the knowledge of naturall things, and all useful Arts, Manufactures, Mechanick practises, Engynes and Inventions by Experiments-_not meddling with Divinity, Metaphysics, Moralls, Politicks, Grammar, Rhetorick or Logick.'" and continues :

"All to advance the glory of God, the honour of the King . . . , the benefit of his Kingdom, and the generall good of mankind."

Not meddling with morals or politics : such, I would urge, is the normal condition of tolerance and immunity for scientific pursuits in a civilised State. I speak not with contempt of these-indeed the scorn with which some superior people talk of such necessities of social existence as morals and polities seems to me intolerabiy childish and stupid. The best intellects and characters, not the worst, are wanted for the moral teachers and political governors of mankind : but science should remain aloof and detached, not from any sense of superiority, not from any indifference to the common welfare, but as a condition of complete intellectual honesty. Emotion, entirely necessary in ordinary life, is utterly out of place in making scientific decisions. If science loses its intellectual honesty and its political independence, if-under Communism or Fascism-it becomes tied to emotion, to propaganda, to advertisement, to 
particular social or economic theories, it will cease altogether to have its general appeal, and its political immunity will be lost. If science is to continue to make progress, it must insist on keeping its traditional position of independence, it must refuse to meddle with, or to be dominated by, divinity, morals, polities or rhetoric.

It is not always possible to avoid such meddling -as the life of Huxley showed. Much of Huxley's time was spent in battling with prejudice, in countering the attacks which were made upon the freedom of science to come to its decisions solely on scientific evidence. The traditional views of divinity, metaphysics and morals, aided by the resources of rhetoric, appeared in array against the Darwinian hypothesis and against evolution in general. Huxley realised the necessity of insisting on the independence of science, on the need of eliminating all other considerations in coming to scientific conclusions. The world, and his country in particular, owe to Huxley a great debt for the freedom he won for science and scientific thought.

Such freedom, however, though fairly and hardly won, is not a permanent and inevitable attribute of science. At intervals it has to be maintained by further struggle. The attachment of certain branches of science to competitive industry, desirable enough within limits, if it went too far might lead to the control of such science by industrial interests. The necessity of science in modern warfare might in some future 'Thirty Years' War give it a purely national instead of an international basis. Its use for propaganda might prostitute it before the world. The coercion of scientific people to certain specified political opinions, as in Russia, Germany or Italy, may lower the standard of scientific honesty and bring science itself into contempt. These possibilities must be watched, and from time to time some champion of scientific independence must stand out, like Huxley, to do battle for freedom.

The present emergency is that of the scientific men and scholars in Germany who have been persecuted, or dismissed, for reasons of race or of independence of opinion. We are witnessing today, all over the world but particularly in Europe, an extraordinary phenomenon, the growth of a peculiar kind of 'nationalism'. Now nationalism, like love of family, is a good thing when tempered with reason. To make your town or community happier, wiser, or more prosperous is a decent and worthy ideal: as I hold it is worthy to try to maintain the traditional hospitality of England to those in other countries who are persecuted for causes other than crime. When, however, nationalism leads to excesses of the kind we have seen in the last years, particularly in the last eight months, not in Europe alone, but all over the world, when violence and hatred are preached as its necessities by otherwise decent people, then indeed one begins to think of nationalism not as a pleasant virtue but as a hideous disease.

As a natural reaction, of course, to nationalism, we see internationalism developing. Internationalism needs no more to be flabby and without character than the puritanism of the seventeenth century, or the movement of the nineteenth to abolish slavery. The tendency to internationalism is displayed in the growth of international law. In literature and art internationalism first made itself felt. To write the history of any literature would be impossible without account of jts foreign indebtedness. If the phrase "the republic of letters" is appropriate, "the republic of science" merely expresses a commonplace. International congresses, international measures of natural constants, geographical and navigational data, and to-day radio, are signs of the common interests of reasonable people in different countries.

As communication became easier and education more widespread, one might have expected that these common interests of mankind would have been more evident. It almost seems to be true, however, that the gods, when they offer one gift, send with it some counter gift to plague mankind. Nationalism in its present embittered form is one consequence of the very forces which-one might have hoped-would have made people realise their common humanity. It would not be difficult for a cynical observer, experienced in neurology, to find exact clinical parallels to those hysterical outbursts of nationalism which make all attempts at a reasonable solution of world problems so difficult.

If there be one single idea which, by common consent and with common applause, represents the contribution of England to the common welfare, that idea is freedom : freedom of action, freedom of belief, freedom of thought and speech. The American Commonwealth was founded by English people on the same idea. Often, it is true, Englishmen have sinned, sometimes grievously, in this respect, but a jealous tradition on one hand, and bitter experience on the other, have kept their country on the whole the freest in the world. Now freedom, like health, may be a citizen's birthright, but it needs safeguarding, it requires a constant effort. Those who will not fight for freedom do not deserve to be free; we must be ready-as Huxley was ready-to take part in the conflict ourselves.

To thinking people, the progress of knowledge, the advance of medicine, the improvement of health and happiness which can be-should bethe result of scientific and technical achievement, are among the major interests of mankind. It seemed that nations and governments were certain, gradually, to realise this, and so would encourage co-operation, at least in intellectual things. Private agencies have contributed very generously in recent times to this end. All over the world, not only in education and in fellowships, but also in field investigations of such diseases as yellow fever and malaria, the Rockefeller Foundation has been contributing (to use the terms of its charter) to the welfare of mankind throughout the world. Its work is done, not in any religious 
fervour, not with flowery language, but as a matter of ordinary business and commonsensenot meddling, as Hooke wrote, with divinity, morals, politics or rhetoric. The voluntary migration of hundreds of young scientific workers under the auspices of the Rockefeller Foundation recalls the movements of earlier times among the universities of Europe. The Rhodes scholarships, the Commonwealth Fund fellowships, the Guggenheim fellowships, serve similar ends.

The history of science, since the War, has been largely of an effort to break down national barriers of mistrust or lack of understanding. It is quite certain that science cannot progress properly except by the fullest internationalism. Accepting freedom of thought and research as the first postulate, the second is that knowledge, however and wherever won, should be freely available for the use of all.

Up to the beginning of the present year one lived in hopes that reason was being restored. Disillusion, however, has been brought to many by the events of the last nine months. No country has excelled Germany in its contribution to science in the last hundred years, no universities were traditionally freer and more liberal than the German. One felt that the intellectual co-operation of Germany was a necessity in setting science on an international basis. I had intended, in this address, to urge an even closer co-operation. Germany, however, has lately rendered such intellectual co-operation impossible by offending the first and most fundamental rule, that providing freedom of thought and research. It seemed impossible, in a great and highly civilised country, that reasons of race, creed or opinion, any more than the colour of a man's hair, could lead to the drastic elimination of a large number of the most eminent men of science and scholars, many of them men of the highest standing, good citizens, good human beings. Freedom itself is again at stake.

The facts are not in dispute. Apart from thousands of professional men, lawyers, doctors, teachers, who have been prevented from following their profession, apart from tens of thousands of tradesmen and workers whose means of livelihood have been removed, apart from 100,000 in concentration camps, often for no cause beyond independence of thought or speech, something over 1,000 scholars and scientific workers have been dismissed, among them some of the most eminent in Germany. These have committed no fault: many of them are patriotic citizens who fought in the German armies in the War. Many of them are of families which have been in Germany for centuries: not all of them are Jews. It is difficult to believe in progress, at least in decency and commonsense, when this can happen almost in a night in a previously civilised State.

What can be done about it? The immediate answer is, of course, that suffering must be relieved and opportunities given for the continuance of their work to those who have been persecuted and deprived. A more important matter, however, is this: we must ensure that the same folly, the same fury, does not occur elsewhere. We cannot take the freedom, so slowly and hardly won, as a birthright: we must see to it that neither race, nor opinion, nor religious belief, nor the advocacy of theories unpopular perhaps at the moment shall cause disinterested able men to be deprived of the means of carrying on their work.

It is a gloomy outlook, and I can see little hope at present except by the strenuous co-operation of intelligent people of goodwill in the various countries. Of one thing, however, one can be certain ; that in a civilisation tottering unsteadily on a foundation of applied science, it is necessary that people scientifically trained should take some part in affairs. That need not imply that Cabinet ministers should be fellows of the Royal Society, but rather that all educated men should have some appreciation, by direct contact, with the methods and ideas of science. It is perilous to disregard the scientific basis of modern civilisation or its dependence on international co-operation.

I do not suppose we can do very much, and I can imagine that Homo sapiens may ultimately destroy, by his irreconcilable folly, all he has built up. His idea of progress, powerful as it is at the moment, may be nothing but an extrapolation from a short portion of a curve. The pterodactyl's achievements in aviation did not prevent it from dying out: it had some fundamental unfitness which, for all its 'progress', put an end to its career upon earth. Mankind's amazing intellectual achievement in understanding and controlling the forces of Nature may be neutralised by the domination of his intellect by his passions, by his emotional inability to realise, what must be obvious to his intellect alone, the demands of a common humanity.

However, I venture still to think of science and learning, particularly science, which in its experimental method has an absolute means of deciding between opinions, as being the strongest links between the intelligent people of the world. Not many Englishmen, unfortunately, know much about the United States of America. Fortunately with scientific people it is otherwise: they have good reason to know that laborious scientific advances on one hand, or brilliant discoveries on the other, are just as likely to be achieved there as elsewhere: and they have that close personal contact with the unassuming friendly people who make these contributions to knowledge, which ensures that the scientific community at least would regard as utterly hateful any serious difference between their countries. This friendly rivalry between Britain and the United States, this sense of co-operation, is a stronger link than many may imagine. We scientific people are often poor, and generally without much honour or position: but in the end we exercise more influence than we know-for our fundamental faith is co-operation in the pursuit of an end outside and greater than ourselves. 